\section{Doomed to Fail:}

\section{Barack Obama's Foreign Policy}

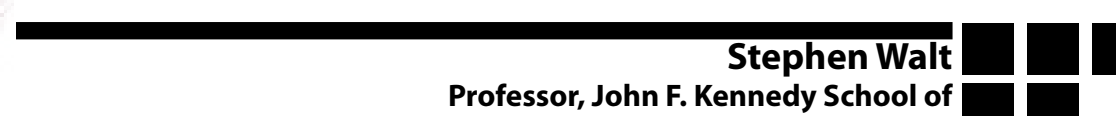

Professor, John F. Kennedy School of

Government, Harvard University

Stephen M. Walt, professor of international affairs at Harvard University's John F. Kenned School of Government, spoke at Cornell on September 16, 2010, at the invitation of the Einaudi Center for International Studies. The following article, produced here with his permission, is an edited transcript of his talk. The board of the Cornell International Affairs Review thanks Professor Walt for his support to our mission.

Back when Barack Obama took office a dramatic transformation in America's global it was a cliche in the media to observe that position, you are going to be disappointed. he was facing the greatest challenge of any president since Franklin Roosevelt. The world economy faced the most serious crisis since the Great Depression, the American image in the world was at historic lows, and he also inherited a number of seemingly intractable foreign policy problems.

There is no question that Obama responded with a lot of activity, almost a dizzying amount. There was an ambitious economic recovery program, a major fiscal stimulus, the buying up of toxic banking assets, a bailout for auto companies and a time consuming effort at healthcare reform. But at the same time, there was a wide array of foreign policy initiatives. We reached out to Iran, hit the reset button with Russia, escalated the war in Afghanistan, and continued to draw down in Iraq. Obama gave a major address to the Muslim world in Cairo, personally attended the climate change summit in Copenhagen brought forty-six leaders together in Washington for a nuclear security summit a few months ago, and convened new peace talks between Israeli and Palestinian leaders. Oh, and one more thing, he won the Nobel Peace Prize.

That's not bad in terms of activity but the question is: what has he actually accomplished? To put it bluntly (and this is the main theme of my talk today) if you thought that Obama's election would produce There are not going to be any major foreign policy accomplishments during his first term, and there may well be some significant setbacks. Now that is partly because there are no easy items on his to-do list. But it is also because his foreign policy team, and the American foreign policy establishment more broadly, is increasingly incapable of making the sort of strategic adjustments that are now needed. In short, no matter how smart President Obama is, how good his instincts are, or how active he might be-and I think he's all three- his foreign policy is doomed to fail.

Let me start by saying a word or two about the problems Obama faced when he entered office. As you all know he entered at a time when the world economy was in its worst shape in decades. American citizens have lost eleven trillion dollars worth of wealth, at least on paper, in 2008. World trade declined in 2009 for the first time in twenty-five years. The world economy shrank in 2009 for the first time since the end of the Second World War. Now I would argue that he acted quickly, and for the most part successfully, to stave off an additional meltdown. It could have been worse. But one consequence of that is a budget deficit that hit 1.8 trillion dollars last year, or about thirteen percent of US GDP. Meanwhile unemployment went over ten percent for the first time since 1983, and although you might argue that things are somewhat better now, nobody expects the American economy to stage a rapid or vigorous recovery anytime soon.

What does that mean? It means that Obama will be dealing with a sluggish economy for his entire first term - if he is lucky. And there are plenty of domestic issues that are not going to be easy or cheap to address. Plus, given the budget deficits that he is facing, Obama is going to have to start cutting budgets soon, and that includes defense and international affairs. This situation will inevitably put limits on what Obama will be able to do in foreign policy.

At the same time, the foreign policy agenda looked equally difficult He inherited a costly and prolonged war in Iraq and a second war in Afghanistan, which, needless to say was not going particularly well. He inherited a stagnant peace process in the Middle East and an American image around the world at historically low levels. Finally, I would add that although the United States remains in some respects the strongest power on the globe by a considerable margin, I would argue that the overall balance of power is gradually shifting States like China, India, Brazil and others are becoming more consequential, better able to protect their own interests, which means America's ability to impose its preferences on others is declining over time.

Given that situation, the obvious thing to try to do is to restore what Walter Lippman used to call solvency - to try and bring American commitments and obligations back into line with the available resources. How do you do that? You extricate yourself from some of your current burdens, you try to improve relations with some potential adversaries, so there are fewer problems to solve, and you try to get others to bear more of the burden. If any of you are looking for a historical analogy, you might think of Nixon and Kissinger. They took office in the midst of a ruinous war and a period of economic weakness, and they sought to reduce America's burdens without sacrificing core interests. So you had detenté with the Soviet Union, an opening to China, Doctrine, which tried to rely more on regional allies.

When he took office, it looked like Obama was trying something similar. He tried to reduce commitments where he could, get allies to do more where he could do that, and tried to improve relations with some current adversaries. I think, by the way, that President Obama knew from the very beginning that this would not be easy, and you can see that from how he put his foreign policy team together. I think he knew the first term was going to be difficult, that economic recovery would take time, that people were going to be hurting, and that there were no low-hanging fruits in foreign policy. The honeymoon was going to end and critics would be ready and waiting to pounce.

So what did he do? He put together a foreign policy team that was designed to insulate the administration from partisan political attacks. He kept Robert Gates as Secretary of Defense, first because he has proven to be a competent manager of a difficult

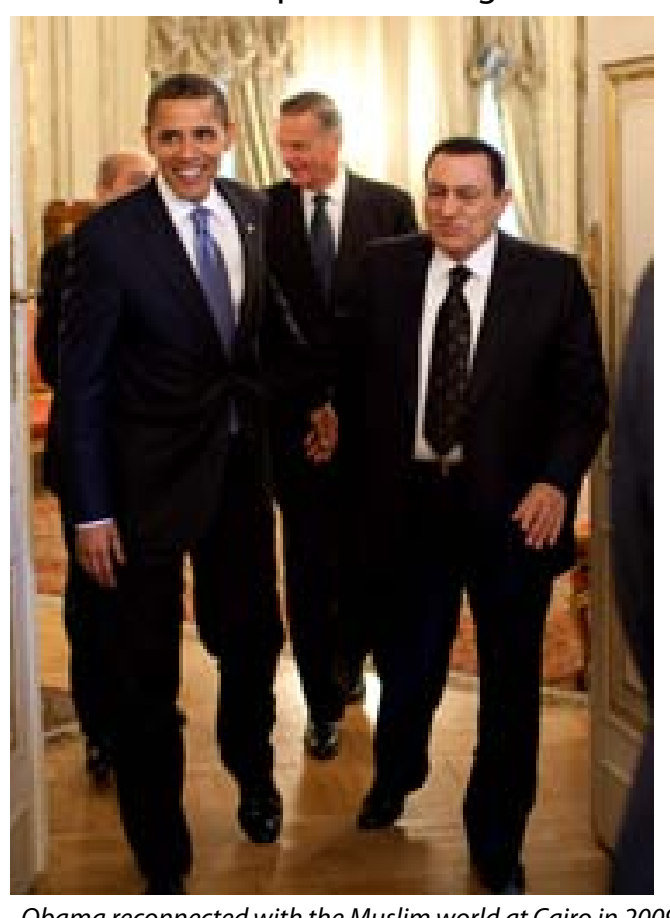

Obama reconnected with the Muslim world at Cairo in 2009 
bureaucracy, but also because he is associated with the Republican party and the so-called "surge" in Iraq, which many see-incorrectly in my view-as a great success. And if you don't like the administration's defense policy, he can point out that he has the same Secretary of Defense that George W. Bush had, which makes it harder for Republicans to criticize

\section{To put it bluntly}

(and this is the main theme of my talk) if you thought that

Obama's election would produce a dramatic transformation in America's global position, you are going to be disappointed.

him. Then he put a four star marine general as head of the National Security Council, which again makes it hard to complain that he is running some kind of left wing foreign policy.

Then he appointed Hillary Clinton to be Secretary of State, not because she was an experienced diplomat, and not because she had a wonderful unique foreign policy vision of her own, but because it unified the Democratic Party and it keeps her from giving speeches in the Senate about how much better things would be if only she'd become president. Bringing Hillary in also guaranteed that the rest of the foreign policy and national security team would be familiar Democratic stalwarts, many of them with experience from the Clinton administration. This is not a foreign policy team from MoveOn.org. These are solid liberal internationalists, one might even say liberal interventionists, who are very comfortable using American power and inclined to think that most foreign policy problems have solutions that are made in America. Virtually all of the top figures backed the Iraq war in 2003, and President Obama is a notable exception among top officials in his own administration.

So with all that as background, what has he actually done? Well I think he has made some important symbolic breaks with the Bush administration. But in terms of substance, there is less change than meets the eye, and nothing that looks like a breakthrough.

First, the symbolism. At his inaugural address, he spoke of "power growing with its prudent use," and said security emanates from "the justice of our cause, the force of our example, and the tempering qualities of humility and restraint." If you contrast that with President Bush's second inaugural speech, which was essentially an anthem to the mission of exporting freedom and democracy around the world, it's really quite striking, and the tone is very different. And it wasn't just speeches: he banned water boarding, he released the Bush era torture memos and condemned these practices openly, he spoke openly about the need for more far reaching arms control in his Prague speech, he extended his hand of friendship to the Muslim world in a speech in Turkey, followed that up with a major speech in Cairo, and made an explicit opening to Iran. So there was a clear difference in tone and I think it had an immediate and tangible results. According to the Pew Global Attitudes Survey, Obama's election produced a sharp and for the most part enduring increase in the percentage of people around the world who now say they have a favorable image of the United States. It was an enormous bump in many parts of the world and it's lasted, until very recently. So in terms of style I think you have to give the administration credit.

But what about the substance? Take counterterrorism, for example. There is less change here than you might think. He said we would close the Guantanamo base within a year-we haven't. The administration has reaffirmed the policy of using military tribunals against suspected terrorists rather than the regular court system. They have retained the principle of preventing detention, meaning holding suspected terrorists indefinitely without trial. Since Obama took office, there have been over seventy-five drone strikes in Pakistan, this is fifty more than in the entire second term of the Bush administration, and in fact it represents seventy-five percent of all drone attacks that have occurred in Pakistan since 2004. And more recently he has even authorized the CIA to assassinate US citizens without trial. I refer here to the case of Anwar al-Awlaki, who is a radical cleric believed to be supporting terrorist groups in Yemen and is a US citizen. The CIA has now been authorized to go after him if they can find him, and kill him if possible. This would normally be considered capital punishment without due process, and we can debate whether or not that makes sense, but it certainly does not suggest a sharp departure from the Bush administration's practice. So again, big difference in terms of tone and style, less difference in terms of substance.

Let me now turn to some of the big items on his foreign policy agenda, starting with Iraq. During the campaign Obama pledged to withdraw from Iraq within 16 months. He then, after becoming president, agreed to a slower timetable after consulting with the Pentagon. But as you all know, a couple of weeks ago he announced an end to combat operations, and indeed American troop levels are down substantially. So you might say that this is one promise he has delivered on. Unfortunately it is also clear that an end of combat operations does not mean an end to the presence of American troops in Iraq, plus thousands of civilian contractors as well. Deep divisions remain in Iraqi society. There is still no central government in Iraq, some six months after their last election. The level of violence has been gradually increasing. The bottom line here is that Iraq is likely to remain violent and unstable for many years, and the United States is likely to be there in strength. My main point is that Iraq is still going to be an important item on the American foreign policy agenda, it will still be there at the end of his first term, and I would guess that it will still be there at the end of his second term, if he gets one. Most importantly, it will not be looking like a success story.
What about Afghanistan and Pakistan? During the presidential campaign he said he wanted to get out of Iraq so we could focus our attention on Central Asia. This was a clever way of looking strong on national security despite his earlier opposition to invading Iraq. So he added seventeen thousand more troops to Afghanistan in the spring of 2009, and after a lengthy review he agreed to send another thirty thousand last fall, who are pretty much all there now. I think a major breakthrough here is unlikely-it is far more likely that ultimately the United States is not going to win this particular war

One the one hand, the administration has been trying to lower everyone's expectations, most notably Secretary Gates' comment back in the spring of 2009 that we're not trying to create some kind of Central Asian Valhalla. (By the way, he really meant Shangri-La, but you get the point.) But it is increasingly clear that the war is not going well. The literature on counterinsurgency tells us that success requires an effective local partner, yet it is increasingly clear that the Karzai government is corrupt, ineffective, and increasingly unpopular. The recent American offensive in Marjah did not produce conclusive results, and related offensive in the Kandahar province was repeatedly delayed and then the expectations for it have been lowered. President Karzai has said in recent months that he doesn't think the United States is likely to succeed, and that he's looking now to open negotiations with the Taliban. Our European allies are increasingly headed for the exits. A few weeks ago a run on the Central Bank of Kabul suggests that the entire Afghan financial order is shakier than we might have thought. The bottom line is that President Obama blundered when he decided to escalate this war.

I would also add that the rationale that has been given for the war-that we are there to deny Al-Qaeda a safe havenremains unconvincing. First, Al-Qaeda already has other safe havens in Pakistan and Yemen, 
and they may actually be better arenas to operate from than Afghanistan. Second, AlQaeda does not need safe havens to attack us. In the latest issue of the New Yorker, there is a long profile of Khaled Sheikh Mohammed, the mastermind of the 9/11 attacks, which shows that $9 / 11$ was primarily planned not from AlQaeda's safe haven in Afghanistan, but from an apartment in Karachi, Pakistan, which tells us that Al Qaeda hardly needs an Afghan "safe haven" to attack us.

Furthermore, even if the Taliban were to win and to invite Al-Qaeda back into Afghanistan, and even if Al-Qaeda were to decide to do relocate there, they would not be able to organize large training bases any longer because we could see them and we could not hesitate to attack them. The bottom line here is that Al-Qaeda is not going to be a lot weaker if we succeed in Afghanistan, and it is not going to be a lot stronger if we fail or withdraw. And if that is so, then why are we fighting a counterinsurgency war designed to create a modern, centralized Westernstyle state, something that has never existed in Afghanistan and that Afghans by most accounts do not want? Also, remember that that war is now costing about one hundred billion dollars per year for a country whose entire GNP is about fourteen billion per year which doesn't sound to me like a very smart piece of cost-benefit analysis.

But even if I'm wrong about all this even if the United States does eventually succeed, it's not going to be anytime soon, and it's not going to be quick or easy. So Afghanistan is going to be on President Obama's desk for the rest of his first term, and I don't think it's going to look like a success story-it's going to continue to look like a political liability for him

What about Iran? Here he made a symbolic move and a clear break with the Bush administration by saying that he wanted to talk to Iran without preconditions and hinting at greater flexibility. He also sent a televised message to the Iranian people, saying he wanted to improve relations. And I think they were hoping to get a break with the presidential elections a year ago; what they got of course is an Iranian government through a fraudulent election that was increasingly challenged and increasingly unable to respond positively to any American overtures, even if they wanted to. But more importantly, there is no sign that Iran is going to suspend nuclear enrichment, and I would remind everyone that the leaders of the dissident movement, including Mir-Hossein Mousavi, support Iran having its own nuclear enrichment capacity. Of course that's the one thing that the United States and most of its allies are saying that Iran cannot have. So even if the Green movement in Iran came to power, the issue of Iran's nuclear program would not go away. The Obama administration has been able to get greater international support for somewhat stiffer sanctions, but there are still no sanctions with real teeth in them. Russia and especially China will continue to drag their feet on this issue, because it is in China's interest for the United States and Iran to be at loggerheads for as long as possible.

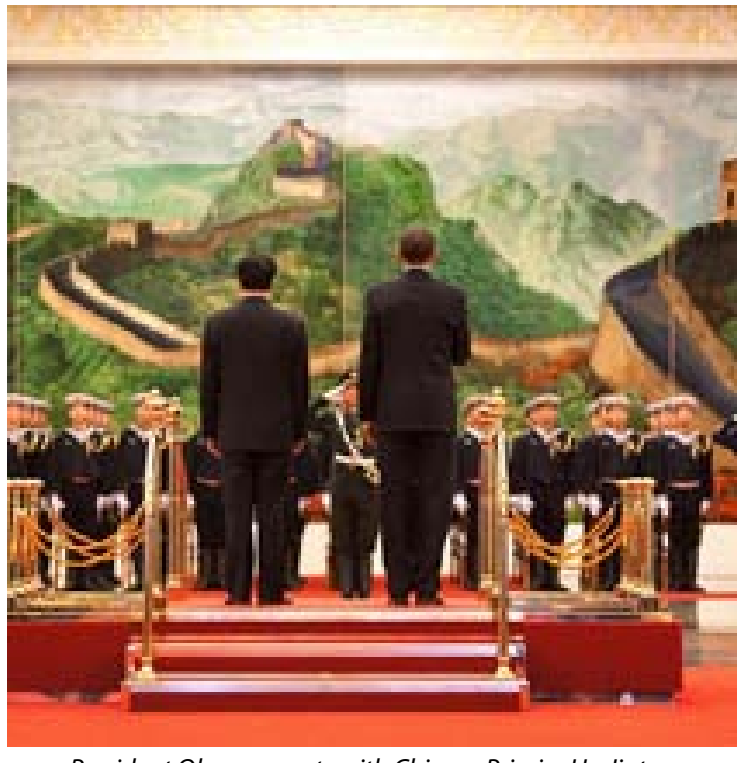

President Obama meets with Chinese Primier Hu Jintao in China - defining the US-China relationship.

Finally, notice that the United States has not tried the one approach that actually might work, a deal where Iran is allowed to enrich uranium under NPT safeguardsprovided it ratifies and implements the Additional Protocol of the Non-Proliferation Treaty and reiterates its decision not to weaponize. In exchange the United States would pledge not to overthrow the regime and not to support movements who are trying to overthrow the regime, something we have done in the past. I am not saying that this proposal would work-I'm not at all sure sure it would-but I think that's the only possible deal that might head off a latent Iranian nuclear capability. And my bottom line here is that there's not going to be a breakthrough, pressure for a harder line is going to increase, and you will still have prominent voices in the United States talking about the need to solve this problem through some form of a military action. This issue isn't going away either.

That brings me to the next item: Israe and Palestine. Obama started off by saying that he was going to push hard for a twostate solution in his first term, and in his Cairo speech in June 2009 he called for the creation of a viable Palestinian state. He said it was in "America's interest, the Palestinian interest, Israel's interest, and the world's interest." He said unequivocally that settlements must stop and that there should be no more natural growth. Now unfortunately the Cairo speech turns out to be the high water mark of this approach, and everything since then has been a humiliating retreat. When he called for a settlement freeze AIPAC got 329 Congressmen and 76 Senators to sign a letter to Obama warning him not to put any pressure on Israel. Israeli Prime Minister Netanyahu refused to agree, initially to even a temporary settlement freeze, said East Jerusalem is not up for discussion, and announced the construction of five hundred additional housing units in August 2009, along with a bunch of new apartments in East Jerusalem. The White House said this was regrettable, but took no other action.

To make matters worse, the administration also dismissed the Goldstone
Report on war crimes during the Gaza War, even though the report condemned both Hamas and Israel. And the administration said virtually nothing when Israel attacked the Gaza flotilla in June. Instead, with elections coming up in November, Obama spent last summer burying the hatchet with Netanyahu, and telling everyone that relations were fine. And frankly this was done for domestic political reasons. Former US Ambassador to Israel Martin Indyk, who by the way used to be deputy director for research at AIPAC, told the Israeli newspaper Haaretz, "American Jews traditionally are pretty supportive of the Democratic Party, they voted overwhelmingly for Barack Obama, and they provide a good deal of funding for political campaigns. So the Jewish factor is always a critical factor for Democratic Candidates. I don't think it's telling any secrets that there are a lot of people who have been upset with President Obama, and I think the White House came to a real understanding that they have a real problem there, and they are going out of their way to show that they are friendly to Israel." Please note those are Martin Indyk's words, not my words, and there is nothing unusual about the behavior he was describing. Presidents routinely try to accommodate powerful interest groups in election years. This is business as usual in the American political system.

Instead of genuine progress, however, what we got was little more than a charade. The Palestinians are not going to accept anything less than a viable state on the West Bank, including a capital in East Jerusalem. Prime Minister Netanyahu has made it clear that the only two-state solution he might offer is a set of disconnected statelets with Israel in full control of their borders, water, and airspace. He has also said repeatedly that settlement building is going to continue in one form or another. And finally, it's clear the Obama administration is not going to put pressure on both sides. If Obama could not get Netanyahu to agree on any serious settlement freeze, 
how could he ever persuade them to give the Palestinians a viable, territorially continuous state of their own including a capital in East Jerusalem?

The bottom line is that there isn't going to be a two state solution, and this problem is going to get worse during Obama's presidency. And the results of this situation are exactly what you would expect. The annual survey of Arab attitudes conducted by the University of Maryland released last month shows that Obama's approval rating in six Arab countries has gone from forty-five percent in 2009 to twenty percent today. Even more remarkable, seventy-seven percent of those surveyed said that Iran had a right to a nuclear program, and fifty-seven percent think the situation in the region would be better if Iran had nuclear weapons-which I consider remarkable. It also reported that the fou most admired political figures in the survey were Prime Minister Erdogan of Turkey, Hugo Chavez of Venezuela, Mahmoud Ahmadinejad of Iran and Hassan Nasrallah of Hezbollah. By the way, all except Chavez are more popular than they were a year ago.

think this is a tragedy for all concerned, as well as a serious problem for the United States. Obama and his team did not act like friends of Israel by caving in, because the likely result will be some form of one-state apartheid, followed by a Palestinian struggle for civil rights. This is precisely what former Prime Minister Ehud Olmert of Israel and the current defense minister Ehud Barak have both warned against. In 2007, Olmert said that "if the two-state solution failed, the Israel will face a South Africa style struggle for political rights. If that happened, he warned, then "the state of Israel is finished." Again that's Prime Minister Olmert talking, not me. Unfortunately, at this point it is hard to imagine this issue turning into a success story during Obama's first term.

Last but not least, let me touch briefly on just a few other issues. Vice President Biden said that we needed to press the reset button with Russia. One could argue they have made some progress there. They did get a new arms control agreement, which will eventually reduce each side's arsenals by about thirty percent. But notice, it will take seven years to produce that thirty percent reduction, and both sides will have lots of overkill left, even seven years from now. But it is progress. He needs sixty-six votes to ratify this agreement and it's not clear he's going to get them. If I had to bet, I would say yes, but I wouldn't bet a lot. More importantly, if the Republicans win a few more seats in November, then additional progress on Obama's nuclear security agenda is bound to be difficult. We're certainly not going to get something more substantial like a comprehensive test ban treaty.

On climate change, he took office declaring strong support for an agreement to replace Kyoto, and he ended up going to Copenhagen for the climate change summit. But as most commentators predicted beforehand, the summit failed to achieve a meaningful agreement, all he got was a sort of face-saving voluntary agreement of little value. I don't really blame this on Obama because climate change might be in many ways the hardest political problem the international community has ever faced. But notice we are ending up in the same place: another item that he declared was an important priority where we are not making much progress. And the midterm elections are not going to make this issues any easier going forward.

Lastly, China. For most of the first year, relations with China were not that bad, but storm clouds are starting to appear with some frequency now. The Chinese have been letting their currency adjust at glacial speed despite considerable American presssure. The Chinese sandbagged Obama at the Copenhagen conference, forcing him to stand outside and wait for his meeting with the Chinese premier. They haven't been helping much on Iran. There have been some minor disputes over access to the internet and irritation over American arms sales to Taiwan. I would argue that the Chinese are secretly thrilled to see the
United States bogged down in places like Iraq and Afghanistan and would love it if we were there forever.

But perhaps most significant of all in recent months the Chinese have been increasingly assertive about declaring the South China Sea and other adjacent waters a vital security zone, and in effect beginning to challenge the American naval presence there. I think this is a harbinger of things to come and these recent frictions remind us that the Sino-American relationship is likely to get increasingly competitive if China's power continues to rise. I might add that this is all the more reason to rethink some of the policies that have made us less popular or have gotten us bogged down in other parts of the world. Now, President Obama may manage this fairly well in the short to medium term, but it is not likely to look like any major achievement or any major breakthrough either.

By this time I hope to have convinced

\section{So even if Barack Obama}

understood that the United

States needed a more restrained

foreign policy, one that avoided international quagmires, relied

more on regional allies, recognized that we are not very good at social engineering on a global scale, he would be hard pressed to find very many people in the foreign policy establishment to support him.

you not to expect very much from the Obama administration when it comes to foreign policy. Before I wrap up, let me explain why think we are having such trouble.

The first reason I already mentioned there are no easy fixes here. On the contrary, this is actually a very difficult to-do list of thorny issues. That's not unusual, of course if problems were easy to fix we might already have solved them.
The second reason is the imbalance of power between the United States and the rest of the world. For all of our current difficulties the United States is still very wealthy and very powerful. We have forces and commitments all over the world. We still play a central role in lots of existing security arrangements. This has two unfortunate effects. First, it is still hard for many American elites to believe that there are things we simply can't do if we just put our minds to it and try hard. Surely, we can defeat the Taliban and create some kind of stable order in Afghanistan. It is hard for Americans to believe that there are some things we just can't do. Second, trying to do less, say getting out of Afghanistan, is likely to have some negative short term consequences. It is therefore tempting for any president to try to muddle through, and to simply pass problems along to your successor.

There is also an imbalance of power here at home. After fifty plus years of cold war, fifty plus years of international activism, the foreign policy establishment in the United States is heavily weighted toward interventionism and especially towards the use of military power. The Republican Party is now heavily shaped by views of neoconservatives, and the Democratic Party is home to liberal interventionists. The latter are for the most part are just kinder, gentler neoconservatives; and the two groups agree far more than they differ. The major think tanks like the Council on Foreign Relations, The Carnegie Endowment, Brookings, AEl, etc., all in the business of identifying global problems and figuring out what the United States should do to fix them. These groups don't always agree on exactly what to do, but doing less is rarely, if ever, one of the choices they recommend. Add to that all of the smaller special interest groups who are trying to get the US government to do more on whatever their particular pet issue is, whether it is in Africa, or Latin America, or Asia or wherever. Then you've got public policy schools, like the Kennedy School where I teach. Our mission is training students to 
go out and solve problems either at home or abroad; you might say that I'm now in the business of training international activists. And if you want a career in the foreign policy establishment, you don't want the United States doing less because that would mean fewer jobs out there.

And finally, I think the professional incentives in the foreign policy establishment increasingly incline its members to favor the use of force. Consider what the former president of the Council of Foreign Relations, Leslie Gelb, recently admitted in an article. He wrote that his own support for the Iraq War-and he did endorse the decision to invade-reflected what he called "an unfortunate tendency within the foreign policy community, namely the disposition and incentives to support wars to retain political and professional credibility." Gelb is saying that to be taken seriously in Washington, you have to show that you are tough and that you are in favor of a hawkish approach to things.

So even if Barack Obama understood that the United States needed a more restrained foreign policy, one that avoided international quagmires, relied more on regional allies, recognized that we are not very good at social engineering on a global scale, he would be hard pressed to find very many people in the foreign policy establishment to support him. It would be darn difficult to staff that particular administration. And that is of course why you are seeing the usual people in the usual jobs pursuing the usual policies we've tried in the past and achieving essentially the same results.

So if I were part of Obama's team-and you might have guessed I'm not likely to beI'd be worried. He's heading into the second half of his first term with a sluggish economy. There's lots of good social science evidence that tells us the state of the economy will play a big role in the next round of elections, both Photos Courtesy of: proven wrong.
Obama and Afghanistan

election in 2012. There are not a lot of big foreign policy accomplishments for Obama can capitalize on and claim credit for in the near term. So if I were a Republican Party But no matter which party you belong to or favor this situation ought to worry you. It's not good when global problems fester, it's not good when the United States engages on issues and fails to make any progress, it's not good when we claim we're going to do something and then we visibly fail, because how to actually achieve things. It makes other countries even less inclined to listen to us in

grim forecast. Mywife and l putasmuch money as the law allowed into Obama's campaign; I voted for him with enthusiasm; and I was thrilled as my children and I sat watching his inauguration. My one consolation, and it may console some of you as well, is that it would have been even worse if the 2008 results had

Which brings me to my very last point. Some of you may remember that President Obama quoted the Koran, the Torah and the Bible in his Cairo speech. Given his fondness for religious texts, I think it is appropriate for me to ent wiblical quotation too, and it sums up the task he now faces. This passage is from the Book of James chapter 2, verse 22: "A man is justified by works, and not by faith alone." Ultimately we are going to judge his foreign policy by what he achieves-by whether he ever earns that Nobel Peace Prize-and not ust by his good intentions. As is probably clear, I am not particularly optimistic about his chances, but I would be delighted to be
James Goldgeier

Professor, Elliott School of International

Affairs, George Washington University

James Goldgeier is professor of political science and international affairs at George Washington University and a 2010-2011 senior fellow at the Transatlantic Academy in Washington, D.C. He taught at Cornell from January 1991 to December 1993. His most recent book (co-authored with Derek Chollet) is America Between the Wars: From 11/9 to 9/11 (Public Affairs 2008), named "a best book of 2008" by Slate and "a favorite book of 2008" by The Daily Beast.

In his campaign for the American General Stanley McChrystal, whose Special presidency, Barack Obama emphasized the Forces background would ensure a keen "right war" in Afghanistan in order both to understanding of what was required to wage highlight the folly of the "wrong war" in Iraq a successful counterinsurgency campaign. and to establish that he was not against all Obama's determination to prosecute wars - just "dumb" ones.' Al Qaeda's safe the war, however, ran into two serious haven in Afghanistan prior to September 11, problems during the summer of 2009. One was 2001 produced the plans and personnel that the failure of Afghan President Hamid Karzai led to the terrorist attacks on New York and to inspire confidence in the legitimacy of his Washington, D.C. Unfortunately, argued government; the August elections involved Obama, the George W. Bush administration massive voter fraud, making it more difficult distracted itself from the job of eliminating to gain public support, either in Afghanistan al Qaeda by bungling its way into Iraq. or the United States, for the American military Emboldened, the Taliban began to undermine effort. The other was the skittishness of the the U.S.-backed Afghan government and DemocraticParty; with an economycontinuing sought to return to power, raising the specter to sour, leading members of Congress, such of a renewed training ground for Islamic as House Speaker Nancy Pelosi (D-CA), made extremists. As president, Obama promised clear their desire to draw down the military the American voters, he would devote the effort, particularly as the number of American resources necessary to successfully prosecute battle deaths continued to rise. the counterinsurgency campaign.

In his first months in office, Obama moved swiftly to fulfill his campaign pledges. He appointed the Democratic Party's star troubleshooter, Richard Holbrooke, as his special representative for Afghanistan and Pakistan. He ordered a strategy review to be completed in his first months in office. Even before the review was finished, Obama had announced a substantial increase in American troops for the conflict, amidst reports that the number would grow even further as the year wore on. And in the summer he inserted as commander of the U.S. forces in Afghanistan
With the announcement that 30,000 additional American troops would head to Afghanistan in 2010 to reverse the momentum of the Taliban balanced against the declaration that those troops would begin coming home the following year, Obama's December 2009 West Point speech highlighted that the president had no good options in Afghanistan. He does not know whether American and allied forces can train Afghans in sufficient quality and quantity to take over responsibility for protecting the government, but he does not want an indefinite American presence.

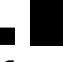

